\title{
The Effectiveness of Behavioral Counseling with Modeling Techniques to Improve Student's Self Autonomy and Self Endurance
}

\author{
Ni Nyoman Sri Ayu Wulandhari ${ }^{\left.1^{*}\right)}$, I Ketut Dharsana ${ }^{2}$, Kadek Suranata $^{3}$ \\ 1,2,3 Universitas Pendidikan Ganesha \\ *Corresponding author, e-mail: ayusriwulandhari4@gmail.com
}

Received August 02, 2021; Revised August 31, 2021;

Accepted Sept. 20, 2021;

Published Online 2021-10-01

\section{Conflict of Interest} Disclosures:

The authors declare that they have no significant competing financial, professional or personal interests that might have influenced the performance or presentation of the work described in this manuscript.

\begin{abstract}
This study aims to determine the effectiveness of the behavioral counseling model with modeling techniques to improve self-autonomy and selfendurance for senior high school students. This experimental study used a pretest-posttest nonequivalent control group design. Through random sampling, 34 students were placed in the experimental group and 32 students were placed in the control group. Data collection used the main data collection method (questionnaire) and complementary data collection methods (observations, interviews, and diaries). The data were analyzed by One-way MANOVA. The results show that there are differences in self-autonomy and self-endurance in the experimental class and control class $(\mathrm{sig}=0.039)$. The results of Cohen D analysis showed a high level of effectiveness $(\mathrm{ES}=0.8)$. These results prove that behavioral counseling with modeling techniques is effective for improving student's self-autonomy and self-endurance.
\end{abstract}

Keywords: Behavioral counseling, modelling techniques, experimental study

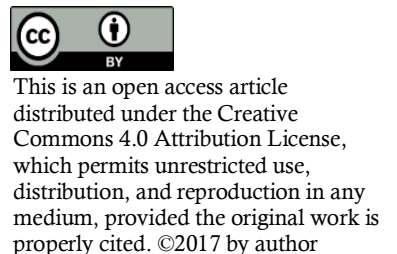

How to Cite: Ni Nyoman Sri Ayu Wulandhari, I Ketut Dharsana, Kadek Suranata. 2021. The Effectiveness of Behavioral Counseling with Modeling Techniques to Improve Student's Self Autonomy and Self Endurance. Bisma, 5 (2): pp. 70-75, DOI: http://dx.doi.org/10.23887/bisma.v5i2

\section{Introduction}

Autonomy is the need to be able to stand alone which includes getting things done well and will succeed, completing tasks and requiring effort followed by expertise and skills, completing something that is very important, carrying out a difficult job, solving a difficult problem, will be able to do something more well, write a famous drama, novel (Dharsana, 2015). According to Stephen Brookfield 2000 (Sutama, Suranata, \& Dharsana, 2014a) suggests that learning independence is self-awareness, self-driven, the ability to learn to achieve its goals. The definition contains the following aspects: (1) self-awareness, (2) learning ability. In the Big Indonesian Dictionary (KBBI) the meaning of independence is a state of being able to stand alone 
without depending on others. The definition contains the following aspects: (1) stand alone (2) without being dependent. (KBBI, 2016)

According to (Chaplin, 2002) Autonomy or independence is the freedom of individual human beings to choose, to become a unit that can govern, control and determine itself while (Hoffnung, RJ, Seifert, 1991) explains Autonomy is "the ability to govern and regulate one's own thoughts, feelings, and actions freely and responsibly while overcoming feelings of shame and doubt". Independence is one aspect of personality that is very important for individuals. In living this life, the individual is never free from trials and challenges. Individuals who have high independence are relatively able to face all problems because independent individuals do not depend on others, always trying to face and solve existing problems.

Individuals who have high independence are individuals who are able to not depend on others, able to stand alone, persistent in business, free to make their own choices, full of initiative, act effectively on their environment, be firm, and consistently in realizing their expectations. Meanwhile, self-endurance means endurance, namely the ability of a person to use his physical and psychological abilities to deal with certain burdens in a relatively long period of time. Endurance is a person's ability to endure or endure pain or adversity or develop effort in the face of adversity.

Storm (1971), suggests "Endurance: To keep of a job until finished, to complete any job undertaken, to work hard at task, to keep at a puzzle or problem until it is solved". Endurance means to keep a job to completion, to finish whatever work is done, to work hard on a task to keep a puzzle or problem until it can be solved. Heald (1971), suggests "Endurance: To keep at a task until it finished, avoid being interrupted while working, and the like". With the understanding that endurance is keeping a task until it is completed, avoiding distractions at work and the like.

Self Endurance is the need to withstand overcoming obstacles including working on a job to completion, trying to get the job done to completion, working hard on a task (Dharsana, 2015). Meanwhile, according to Hatta (Sugiyanto, 1984), endurance is the need to be able to withstand the obstacles that exist in life, both those that come from within and from the surrounding environment. Individuals who have high Endurance will not easily despair when encountering obstacles, they will continue to struggle and be serious about achieving their goals. Based on the Regulation of the Minister of Education and Culture of the Republic of Indonesia No. 20 of 2018 concerning Strengthening Character Education in Formal Education Units Article 2 paragraph 1 explains that "Strengthening Character Education is carried out by applying Pancasila values in character education, especially including religious values, being honest, tolerant, disciplined, working hard, being creative, independent. , democratic, curiosity, national spirit, love for the homeland, respect for achievement, communicative, love peace, love to read, care for the environment, care about social, and be responsible" (Kemendikbud, 2018).

Character education is important to improve individual abilities in dealing with existing obstacles. Each individual has different obstacles and difficulties in life and the way of solving it is different depending on each individual. However, it is expected that each individual has good abilities in dealing with difficulties, does not give up, completes the work he receives, tries his best to solve the problems he is facing (Cleland, J., Arnold, R., \& Chesser, 2005). The importance of character education is to improve one's abilities when dealing with problems, difficulties and obstacles that come in his life. Everyone has different problems, difficulties and obstacles in their life and also how to face and resolve and deal with them is different, this depends on each individual. Everyone is strived to have optimal ways and abilities when dealing with obstacles, to have confidence and optimism to be able to complete every given job as well as possible to be able to find a way out of the problems he is facing so as to be able to complete every job he receives.

Based on observations in class XI C Accounting with a total of 30 students consisting of 9 boys and 21 girls in study by Sutama, Suranata, \& Dharsana (2014), most of the 30 students were very active without being appointed to answer questions., students do not cheat in making assignments, students pursue homework by themselves, do not complain when given additional assignments by the teacher, are responsible for making assignments. However, most students show symptoms of having to be appointed in answering questions in a discussion, copying other people's work, and telling others to do homework, always complaining when the teacher is given additional assignments, less responsible. From these symptoms, researchers can conclude that this behavior shows that students are less independent in learning. (Sutama, Suranata, \& Dharsana, 2014b) 
In addition, research conducted by Yunidar, Gading, \& Dharsana (2015) at SMAN 1 Sukasada showed that some students were less disciplined, less able to complete assignments, and did not work hard on a task. The results of observations made by researchers on class X students in the daily life of students at their school show characters such as 1) working on a task until it is finished $10 \%, 2$ ) trying to complete a job to completion $10 \%, 3$ ) working hard on a task $9 \%$, , but However, not all students show symptoms of this behavior, there are some students who show the opposite behavior such as ignoring the assignments given by the teacher $5 \%$, lazy to do so that tasks accumulate $7 \%$, preferring to relax $8 \%$ and playing games rather than spelling. assignment of $6 \%$ observations was strengthened to analyze the data. (Gita Yunidar, Gading, \& Dharsana, 2015)

The author tries to investigate this in another school, namely SMA Dwijendra Denpasar. From the results of observations and observations made at SMA Dwijendra Denpasar at the beginning of the 2020/2021 school year, in the Covid-19 pandemic situation, it was found that many students with symptoms of pessimistic attitudes and behavior, easily gave up facing obstacles and obstacles found during the learning process and were less serious. in doing a task. The results of interviews with lesson teachers and also from observations obtained that students tend to ignore the tasks given, choose to cheat and copy the work of friends to neglect to complete the tasks given. After conducting interviews with these students, information was obtained on how students' attitudes towards the tasks assigned to them were obtained. Some students stated that they were serious about working on and completing the assignments given in various ways, others only doing their best and some even didn't want to do it because they thought the task was difficult. can't do the work on their own. This is also reinforced by the results of collecting psycho test data (Interests and Talents) for class X students at SMA Dwijendra Denpasar which shows that self-autonomy shows at a moderate level and self-endurance which shows that a small proportion of students have moderate selfendurance and most have self-restraint. low endurance.

Seeing the counselee's problems related to self-autonomy and self-endurance, the advantages and disadvantages of each theory and the researcher's ability to apply existing counseling theories, the researchers chose the behavioral counseling model modeling technique to develop self-autonomy and self-endurance in class X SMA Dwijendra Denpasar. According to Gerald Corey (Corey, 2009) Behavioral counseling is a counseling theory which is basically formed and determined by the environment and all of its behavior is learned or acquired through the training process. Behavioral counseling theory is a comprehensive theory as well as an experimental effort to explain the principles and rules of how human behavior is studied (Dharsana, 2013)

While Modeling is a technique by imitating a person's behavior either directly or from symbolic imitation. The term modeling is a general term to indicate the occurrence of the learning process through observation from others and the changes that occur because of it through imitation. Modeling is one of the counseling techniques developed by Albert Bandura which is rooted in social learning theory (Dharsana, 2015). According to Bandura (Corey, 2005) "modeling techniques are modeling observations, observing someone else so that someone forms ideas and behavior, then explained as a guide to action". (Corey, 2009). The provision of behavioral counseling with modeling techniques can be done online, namely by using google meet.

The expected goals of this study are to analyze the differences in the levels of self-autonomy and selfendurance in Class X students of SMA Dwijendra Denpasar who were given the Modeling Behavioral Counseling Model and those who were not given any counseling. To find out and describe the effectiveness of the Behavioral counseling model with effective modeling techniques in improve the self-autonomy of the tenth graders of SMA Dwijendra Denpasar, To find out and describe the effectiveness of the Behavioral counseling model with effective modeling techniques in increasing the self-endurance of the tenth graders of SMA Dwijendra Denpasar. Based on the description above, the researcher formulated this study with the title The Effectiveness of Behavioral Counseling Models With Modeling Techniques To Improve Self Autonomy and Self Endurance (Experimental Study on Class X Students of SMA Dwijendra Denpasar). 


\section{Method}

\section{Research Procedure}

The research design used was a pretest-posttest nonequivalent control group design. (Dantes, 2012) states that in quasi research, "intact groups" are often used, such as classes so that randomization cannot be done. The population in this study were students of class X SMA Dwijendra Denpasar, amounting to 286 students. The research sample amounted to 66 students. Through random sampling technique, 34 students were placed in the experimental group who received behavioral counseling model treatment with modeling techniques and 32 students were in the control group. The experimental group and the control group were given a pretest questionnaire first. Then the experimental group was given treatment using cognitive restructuring techniques for 8 meetings. The treatment steps given are: (10 defining goals, (2) showing the behavior to be modeled, (3) concluding the modeled behavior, (4) practicing the model behavior, (5) assigning to the counselee, and (6) behavior evaluation. While the control group waited to get counseling after the study ended. Such groups are often referred to as waiting list controls. After the treatment was completed, all experimental and control classes were given a posttest questionnaire.

\section{Data Collection Method and Data Analysis Procedure}

Data collection methods are divided into: (1) main data collection methods and (2) complementary data collection methods (observation, interviews and diaries). The main data collection method is a questionnaire. The questionnaire used in this study has been tested for validity first. Content validity was determined using expert/expert agreement and 30 self-autonomy statements were obtained and 30 self-endurance statements were valid. To determine reliability, Cronbach's Alpha formula is used. In this reliability test using the Alpha coefficient method (a) or r Alpha, to test the reliability used with the help of SPSS Version 26.0 for windows. From the results of reliability testing using SPSS Version 26.0 for windows, the self-autonomy research instrument was declared to have high reliability because it obtained an $\mathrm{r}$ alpha of 0.720 and the self-endurance instrument also had high reliability because it obtained an $\mathrm{r}$ alpha of 0.746 where both $\mathrm{r}$ alpha results were greater than $\mathrm{r}$ table of 0.116 with $\mathrm{N}=286$ and a significance level of $5 \%$. So, these two instruments are feasible and can be used as a data collection instrument.

The data analysis technique in this study was to determine the difference between self-autonomy and selfendurance in the treatment group and the control group, as well as to determine the effectiveness of behavioral counseling modeling techniques in improving students' self-autonomy and self-restraint. Posttest Self Autonomy and Self Endurance data uses One-way Multivariate Analysis of Variance (One-way MANOVA) through SPSS 23 to analyze whether there are differences in the behavioral counseling model of modeling techniques in improving students' self-autonomy and self-endurance in the experimental group and the control group (Schober). , P. Boer, C. Schwarte, 2018). Followed by using d'Cohen to calculate the level of effectiveness of the treatment carried out. (Becker, 2000).

\section{Results and Discussion}

At the data analysis stage, the data that has been obtained from the research are described according to the experimental group. In this study, the differences between pretest and posttest were sought from the scoring of the self-autonomy and endurance questionnaires. As for the descriptive analysis for students' selfautonomy and self-endurance, it is presented in Table 01 below.

Table 01. Descriptive Analysis of Student's Self Autonomy and Self Endurance

\begin{tabular}{ccccc}
\hline \multirow{2}{*}{ Data Statistics } & \multicolumn{2}{c}{ Self Autonomy } & \multicolumn{2}{c}{ Self Endurance } \\
\cline { 2 - 5 } & Pre-Test & Post-Test & Pre Test & Post Test \\
\hline N & 34 & 34 & 34 & 34 \\
Mean & 98,50 & 109,53 & 99,82 & 106,06 \\
Mode & 98 & 117 & 92 & 102 \\
Median & 98 & 109 & 99,5 & 105 \\
SD & 9,90 & 9,37 & 7,08 & 8,39 \\
Varians & 98,08 & 87,77 & 50,15 & 70,42 \\
Minimum Score & 74 & 91 & 87 & 92 \\
Maximum Score & 114 & 129 & 118 & 127 \\
Data Range (Range) & 40 & 38 & 31 & 35 \\
\hline
\end{tabular}


After taking the pretest, the average self-autonomy score in the experimental group was 98.50. After following the treatment and answering the questionnaire in the post-test, the average score of self-autonomy in the experimental group showed an increase compared to the pre-test, which was 109.53. While the pretest average self-endurance score in the experimental group was 99.82. After following the treatment and answering the questionnaire in the post-test, the average self-endurance score of the experimental group showed an increase compared to the pre-test, which was 106.06. To analyze the differences in self-autonomy and self-endurance in the experimental group and the control group, One-Way Manova was used, using SPSS 23 for Windows. The calculation results are presented in Table 02 below.

Table 02. The Result of One-way MANOVA

\begin{tabular}{lccl}
\hline Test Analysis & F & Sig. & Decision \\
\hline $\begin{array}{c}\text { Hotelling's } \\
\text { Trace }\end{array}$ & 2,963 & 0,039 & Ho rejected \\
\hline
\end{tabular}

Based on Table 4.22, the results of the MANOVA test with Hotelling's Trace analysis show a significance value of 0.039 which is smaller than 0.05 (H0 is rejected) so it can be concluded that there are differences in self-autonomy and self-endurance in the experimental class and control class. One Tailed Paired is used to analyze the effectiveness of each dependent variable, namely self-autonomy and self-endurance. The results of the one tail paired test for self-autonomy, namely the Behavioral Counseling Model Modeling Technique is effective in increasing students' self-autonomy. This is because the value of sig. $<0.05$ which is 0.00 , so Ho is rejected. The results of the one tailed paired test for self-endurance, namely the Behavioral Counseling Model Modeling technique is effective in increasing students' self-endurance. This is because the value of sig. $<0.05$ which is 0.00 so Ho is rejected. Based on the ES value obtained from the analysis of SPSS 23 for windows (Partial Eta Squared) that is 0.806 . Because the ES value $>0.8$ is high, so with ES $=0.806$ it can be said that "The effectiveness of the behavioral counseling model of modeling techniques to improve selfautonomy and self-endurance of class X students of SMA Dwijendra Denpasar" is classified as having high effectiveness.

\section{Conclusion}

Based on the results of this study, several suggestions can be made to improve the quality of guidance and counseling services in the future (1) for guidance and counseling teachers or counselors, they should be able to apply behavioral counseling models with these techniques as an alternative in providing guidance and counseling services to counselees (students) who have problems in self-autonomy and self-endurance. In addition, guidance and counseling teachers (counselors) can also apply behavioral counseling models of this modeling technique to students (counselees) that are tailored to the needs and characteristics of students. (2) for schools, it is hoped that schools will continue to provide support and facilities for other researchers to be able to conduct similar research in order to meet the needs of students through guidance and counseling services in the hope of producing quality graduates with the formation of civilized behavior. (3) students' diaries used in this research, it is felt that there are still many shortcomings, especially in the counselee's activities section. For this reason, it is recommended that further researchers conduct similar research using diaries to further optimize research and increase student activity, and motivate students to fill out the diaries. Then research related to this modeling technique needs to be done with other dependent variables and involves a wider sample. (4) policy makers, especially guidance and counseling, should consider the provision of counseling theory and techniques in this study as an innovation in the field of guidance and counseling. Before providing counseling services to students, RPBK should be prepared both classical guidance, group guidance, and individual counseling in order to adjust service delivery to the procedures and implementation steps. 


\section{Acknowledgment}

This research written to fulfill one of the requirements to obtain a Master of Education degree in Counseling Guidance Study Program in Universitas Pendidikan Ganesha. The completion of this study has received a lot of help from various parties. May all the help they have given in completing this study, blessed with commensurate rewards by God Almighty, health, and harmony in living life. The author realizes that this thesis is not perfect, but its presence in the constellation of the academic community will add to the treasury of knowledge in the development of science. Hopefully this research will be useful for the academic community.

\section{References}

Becker, L. A. (2000). Effect Size Measure for Two Independent Groups. Jurnal Effect Size Beeker, (1993), 3.

Chaplin, J. P. (2002). Kamus Psikologi. (terjemahan : Kartono). Jakarta: PT. Raja Grafindo Persada.

Cleland, J., Arnold, R., \& Chesser, A. (2005). Failing finals is often a surprise for the student but not the teacher: identifying difficulties and supporting students with academic difficulties. Medical teacher.

Corey, G. (2005). Teori dan Praktek Konseling \& Psikoterapi (Koswara.E, ed.). Bandung: PT.Refika Aditama.

Corey, G. (2009). Teori dan Praktek Konseling dan Psikoterapi. Bandung: PT.Refika Aditama.

Dantes, N. (2012). Metode Penelitian. Jogjakarta: ANDI.

Dharsana, K. (2013). Teori-teori Konseling. Singaraja: BK FIP Undiksha.

Dharsana, K. (2015). Seri RPBK untuk Pengembangan Variabel Terikat Self-3. Singaraja: BK FIP Undiksha.

Gita Yunidar, N. M. I., Gading, I. K., \& Dharsana, I. K. (2015). Behavioral Counseling with Effective Modeling Techniques to Improve Self Endurance in Students. 4(1), 23-29. https://doi.org/https://ejournal-pasca.undiksha.ac.id/index.php/jurnal_bk/article/view/3272

Hoffnung, R.J., Seifert, K. . (1991). Child and Adolescent Development. ((2nd Ed). Boston: Houghton Mifflin Company.

KBBI. (2016). Kamus Besar Bahasa Indonesia (KBBI) (Kelima). Diambil dari https://indonesia.go.id/kategori/pendidikan/1299/kamus-besar-bahasa-indonesia-kbbi-daring

Kemendikbud. (2018). Permendikbud RI No 20 Tahun 2018. Permendikbud Nomor 20 tahun 2018 tentang Penguatan Pendidikan Karakter pada Satuan Pendidikan Formal, 8-12. Diambil dari https://jdih.kemdikbud.go.id/arsip/Permendikbud_Tahun2018_Nomor20.pdf

Schober, P. Boer, C. Schwarte, L. A. (2018). Correlation coefficients: Appropriate use and interpretation. Anesthesia \& Analgesia.

Sugiyanto. (1984). Psikologi Pendidikan. Semarang: UNNESA.

Sutama, G. A., Suranata, K., \& Dharsana, K. (2014a). Penerapan Teori Behavioral Dengan Teknik Modeling Untuk Meningkatkan Kemandirian Belajar Siswa Kelas AK C SMK Negeri 1 Singaraja. ejournal Undiksa Jurusan Bimbingan Konseling, 2(1), 1-11.

Article Information (Supplementary)

Conflict of Interest Disclosures:

The authors declare that they have no significant competing financial, professional or personal interests that might have influenced the performance or presentation of the work described in this manuscript.

Copyrights Holder: <wulandhari $><2021>$

First Publication Right: BISMA The Journal of Counseling

https://doi.org/10.xxxx/xxxxx

Open Access Article | CC-BY Creative Commons Attribution 4.0 International License.

@creative

Word Count: 